\title{
Analysis of model-based PM2.5 emission factors for on-road mobile sources in Mexico
}

\author{
M. ZAVALA, H. BARRERA, J. MORANTE and L. T. MOLINA \\ Molina Center for Energy and the Environment, La Jolla, California, USA \\ Corresponding author: Miguel Zavala; e-mail: miguelz@mce2.org
}

Received October 14, 2011; accepted September 4, 2012

\begin{abstract}
RESUMEN
Se investigan los resultados del empleo del modelo US-EPA MOVES2010a para calcular los factores de emisión del parque vehicular mexicano, y se comparan dichos resultados con las estimaciones del Inventario Nacional de Emisiones de México (INEM) de 2005. El estudio muestra que los factores de emisión PM2.5 basados en modelos, actualizados a partir de estudios recientes, pueden tener un impacto significativo en la estimación de emisiones de PM2.5 procedentes de fuentes móviles en México. Porcentajes mayores de vehículos antiguos tienden a incrementar las estimaciones de emisiones PM2.5 cuando se utiliza el modelo MOVES2010a en comparación con las del INEM 2005; sin embargo, el impacto global sobre las emisiones de material particulado varía según la cantidad y antigüedad de los vehículos, y de acuerdo con los porcentajes de vehículos antiguos impulsados por diesel y gasolina en el parque vehicular de cada entidad federativa. Los resultados también indican que las estimaciones de PM2.5 con MOVES2010a fueron particularmente sensibles a la velocidad vehicular, la temperatura ambiente y el contenido de azufre, pero no a la humedad relativa. Hay una gran necesidad de comprender las características del material particulado fino emitido por vehículos impulsados por diesel o gasolina en las principales zonas urbanas de México.
\end{abstract}

\section{ABSTRACT}

This study investigates the effects of using the US-EPA MOVES2010a model for estimating PM2.5 emission factors in the Mexican vehicle fleet; the results are compared with the current PM2.5 emissions estimates in the 2005 Mexican National Emissions Inventory (MNEI). Our results show that model-based PM2.5 emissions factors updated from recent studies can have significant impacts on the estimated PM2.5 emissions from mobile sources in Mexico. Higher fractions of older vehicles tend to increase PM2.5 emissions estimates using MOVES2010a with respect to the 2005 MNEI estimates; however, the overall impact on PM emissions varies depending on the vehicle population and vehicle age composition for each Mexican state fleet. These effects are primarily driven by the higher PM2.5 emission factors from the gasoline-powered vehicles and by the high fractions of older gasoline and diesel vehicles. The results also indicate that the estimated MOVES2010a PM2.5 emission factors for Mexico were particularly sensitive to vehicle speed, ambient temperature and sulfur content, but not the relative humidity. There is a strong need to better understand the characteristics of fine particulate matter (PM) emitted from gasoline and diesel-powered vehicles in major urban areas in Mexico.

Keywords: PM2.5 emission factors, mobile sources, emissions inventory. 


\section{Introduction}

The effects of atmospheric particulate matter (PM) on human health have been well documented in recent years; the overall literature provides reasonably compelling evidence that ambient PM air pollution contributes to cardiopulmonary morbidity and mortality (e.g., Pope, 2010). There is also evidence of induced hemolysis and DNA degradation from PM (Osornio et al., 2011; Quintana et al., 2011). Furthermore, airborne PM adversely affects visibility and ecosystems, and influences climate. Yet, there are still large uncertainties in the characterization of the properties, composition, evolution, and sources of PM in many urban as well as rural areas. Therefore, it is important to address the uncertainties in the characterization of PM during the design of future air quality management programs (Bachmann, 2010).

Emissions from on-road mobile sources contribute substantially to harmful concentrations of airborne particulate matter in many urban areas and the PM emissions estimates from mobile sources is currently a major challenge and an active area of research (CRC, 2010). For example, recent field studies in Mexico City (Molina et al., 2007, 2010) have shown that mobile sources emit abundant amounts of primary PM and that their emissions estimates in current official emissions inventories are highly uncertain (Aiken et al., 2009; Zavala et al., 2009a). Uncertainties in emissions inventories may arise when model-based techniques are used for the estimation of PM emissions from mobile sources due to propagations of uncertainties in: (1) the databases for inventorying and classifying the vehicle's activity levels, number and fuel characteristics, as well as roads type, driving modes, and ambient data representative of the local conditions; (2) the use of non-locally measured and model-based emissions factors. Because these sources of uncertainties are common during the use of "bottom-up" techniques for the development of emissions inventories, it is expected that similar error propagations may apply to PM emissions estimates from mobile sources in other urban areas of Mexico. Therefore, the extent at which non-locally measured and modeled-based emissions factors can be used for estimating PM emissions from mobile sources in Mexico is an important research question.

Research on emissions from mobile sources in Mexico first started in the 1990s focusing on gas-phase emissions in the vehicle fleets in Mexico City and a few other cities using remote sensing techniques (Beaton et al., 1992; Bishop et al., 1997), a tunnel study (Múgica et al., 1998), and analyses of ambient data (Riveros et al., 1998). These earlier studies showed that hydrocarbon and $\mathrm{CO}$ emissions from vehicle fleets in Mexico in general were vastly greater than in cities in North America or Europe at that time, partly due to the large fraction of vehicles without emission control devices. Most of these studies used dynamometer-based measuring techniques and investigated the effects of various parameters such as types, properties, and blend characteristics of fuels (Gamas et al., 1999; Díaz et al., 2000; Schifter et al., 2000a, b, c, 2001, 2003a, 2004), engine technology (Schifter et al., 2000d; Jazcilevich et al., 2007), toxic emissions (Schifter et al., 2000e), and inspection and maintenance programs (Riveros et al., 2002; Schifter et al., 2003b) on the emissions from light-duty gasoline vehicles. These laboratory studies helped to better understand the emission characteristics of the vehicle fleet in Mexico City at that time and were pivotal for supporting and designing emission-based air quality control strategies. Nevertheless, these studies mostly focused on gas-phase emissions factors from light-duty gasoline vehicles in Mexico City and there is still a large gap of PM emissions measurements and information on emissions from vehicle fleets in the rest of the country.

More recent measurements of emissions factors from mobile sources in Mexico City under realworld driving conditions were obtained using remote sensing techniques (Schifter et al., 2003c, 
2008), and mobile laboratory measurement techniques in the dedicated MCMA-2002/2003 and MILAGRO/MCMA-2006 field campaigns (Jiang et al., 2005; Rogers et al., 2006; Zavala et al., 2006, 2009a, c; Thornhill et al., 2010). These studies provided valuable information on the chemical composition of gases and PM emitted from mobile sources in Mexico City and highlighted the important contributions of emissions from diesel-powered vehicles to pollutants concentration levels in Mexico City. However, there is a strong need to better characterize fine PM emitted from diesel-powered vehicles in other urban areas in Mexico and to evaluate the current emissions estimates using a combination of measurement and model-based techniques.

The US Environmental Protection Agency (EPA), the Coordinating Research Council (CRC), and several other US state agencies recently completed a field measurement program to evaluate exhaust PM emissions from medium and light-duty, gasoline-powered vehicles in the Kansas City Metropolitan Area (EPA, 2008). The Kansas City study confirmed that PM emissions from light-duty gasoline-powered vehicles are higher than earlier predicted, and clearly showed the important effect of the variations of ambient temperature on PM start emissions. As an outcome from the Kansas City study, EPA has upgraded and vastly improved the PM emissions estimates in the Motor Vehicle Emissions Simulator version 2010a (MOVES2010a), currently the most advanced model for estimating on-road mobile emissions at national, state, county, and project level. The recently upgraded model MOVES2010a has also improved the PM emissions estimates from diesel-powered vehicles by incorporating new data from a large study of emissions from heavy-duty vehicles conducted by CRC (CRC, 2007), which also includes deterioration effects on in-use diesel-powered vehicle emissions. MOVES2010a can also generate emissions estimates at multiple geographical scales, from national level to county or local level, and with high temporal resolution. As a result, MOVES2010a is currently the EPA recommended model for the development of emissions inventories in state implementation plans (SIP), as well as for preparing regional emissions estimates for regulatory and transportation conformity applications (EPA, 2010).

Recently, federal and state governmental agencies from several urban areas in Mexico have started developing local emissions inventories, which include the estimation of emissions from mobile sources using bottom-up techniques. At the national level, the first comprehensive Mexican National Emissions Inventory (MNEI) for the year 1999 was released in 2006 (SEMARNAT, 2006). The inventory for the year 2005 was released in December 2011 by the Secretaría de Medio Ambiente y Recursos Naturales of Mexico in collaboration with the Commission for Environmental Cooperation of North America (CEC) (SEMARNAT, 2011). The 2005 MNEI inventory uses the MOBILE6.2-Mexico model for the estimation of emission factors for mobile sources. Similar to previous versions of this model, MOBILE6.2-Mexico requires several inputs including road type, driving modes, fuel type and vehicle technology characteristics for the vehicle fleet, as well as local altitude and meteorological conditions; all of which need to be compiled or estimated by the federal, state, and local agencies. The emissions factors obtained are then combined with vehicle fleet population data and distributions of vehicle-kilometers traveled for the estimation of the emissions from mobile sources per vehicle type. The MOBILE6.2-Mexico model is based on results from measurements obtained using certification vehicles operating during prescribed driving cycles to simulate rural and urban road condition types, instead of using real world onroad driving conditions. In contrast, the MOVES2010a model now incorporates the results from recent research on in-use vehicles and trucks for the estimation of vehicle emissions by emissions processes (e.g., idling, exhaust, crankcase, starts). 
In this study we investigate the effects of using MOVES2010a to estimate PM2.5 emission factors in the Mexican vehicle fleet and compare our results with the current PM2.5 emissions estimates in the 2005 MNEI. We show that the recent studies and updated model-based databases of PM2.5 emissions factors used for the development and evaluation of the MOVES2010a model can have significant impacts on the estimated PM2.5 emissions in the MNEI from mobile sources in Mexico. By identifying the main parameters that affect the PM2.5 emission estimations, the results can also be used to provide recommendations for developing on-road PM2.5 emission factors representative of the Mexican vehicle fleet.

\section{Methodology}

\subsection{Experimental procedure}

To assess the potential impacts of using the recently updated model-based databases in the estimation of PM2.5 emissions from mobile sources in Mexico, we have compared PM2.5 emission factors estimated with the MOVES2010a model and the bulk emission factors used in estimating PM2.5 mobile emissions in the 2005 MNEI. The results were analyzed on the basis of key input model parameters, including vehicle fleet characteristics (vehicle type composition, fleet size, model year) and fuel type. For the comparison we have used the same 2005 base-year vehicle fleet input information compiled for each Mexican state during the estimation of PM and gaseous emissions from mobile sources in the 2005 MNEI. The 2005 MNEI presents the PM2.5 emissions estimations from on-road and off-road mobile sources for the 32 Mexican states and by municipality, obtained using the MOBILE6.2-Mexico model originally prepared for the Western Government Association (WGA) by Eastern Research Group (ERG) as part of the development of the 1999 MNEI (SEMARNAT, 2011).

\subsection{Models description}

The input source data needed for using the MOBILE6.2-Mexico model included vehicle registration statistics, meteorological data, fuel characteristics, data from inspection and maintenance programs, and vehicle-kilometers traveled and travel-demand models for Mexican vehicle fleets that were compiled with information from federal, state, and local agencies for developing vehicle activity data. The model classifies the vehicle types by gross vehicle weight rating (GVWR) and by fuel type; for example: motorcycles (MC), light-duty diesel trucks (LDDT), heavy-duty diesel vehicles (HDDV), heavy-duty gasoline vehicles (HDGV), light-duty gasoline trucks (LDGT), and light-duty gasoline vehicles (LDGV) are some of the main vehicle classes used. The model requires further classification of these vehicle types by specific ranges of GVWR, resulting in indexed vehicle subtypes (e.g., LDGT1, LDGT2, etc.). Although MOBILE6.2 allows the estimation of emission factors for various emission processes (e.g., brake wear, tire wear, crankcase, well-to-pump, etc.), for consistency in our comparison with MOVES2010a we have included only the running exhaust emission processes that were used in MOBILE6.2-Mexico for PM2.5 emissions estimates in the 2005 MNEI.

Although both MOBILE6.2 and MOVES2010a models share the same basic concept of determining emission factors for various vehicle classes, they have very different approaches and levels of data-details needs. For example, the more detailed approach used in MOVES2010a allows 
users to incorporate a variety of activity data to better estimate emission differences such as those resulting from changes to vehicle speed, in-use deterioration rates, and meteorological conditions. In addition, MOVES2010a uses a different emission rate for each combination of vehicle source type, age group, and driving mode. As a result, MOVES2010a emission rates are based on driving modes that can account for different patterns of acceleration, cruising, and deceleration, as well as average speed, while MOBILE6.2 is based on aggregated driving cycles and only accounts for differences in average speed.

The different approaches and levels of data details used in MOBILE6.2 and MOVES2010a require transformations of input data into databases format. We achieved this by using the open source MySQL database management software, which required migrating the MOBILE6.2 input formats used in the 2005 MNEI to MOVES2010a input databases. For example, a major difference on input formats between both models is the way in which the vehicle types are classified. Whereas MOBILE6.2 classifies the vehicle types by GVWR and by fuel type, MOVES2010a categorizes the vehicles into 13 source types based on the vehicle classification scheme used in the Federal Highway Administration's Highway Performance Monitoring System (HPMS). This vehicle classification was chosen in MOVES2010a to make it easier to use state motor vehicle registration data and highway activity information. The vehicle type classification data input files in MOBILE6.2-Mexico format were transformed into equivalent databases in MOVES2010a format using the converting tools available at the EPA website (EPA, 2010).

The MOVES2010a model uses a graphical users interphase (GUI) for providing all the data input requirements within a run-specification (RunSpec) framework. The RunSpec allows the user to specify all the parameters that control a model scenario including: base calculation year, temporal data input distributions, geographical locations, spatial scale, type of pollutants, vehicle types, inspection and maintenance programs, fuel types, output options, and calculation type. For our analysis we used the "Inventory" model's calculation type, allowing us to perform calculations of the PM emitted mass within a region and time span for the selected pollutants, in contrast to the "Emission rates" calculation type that only allows to calculate the emissions mass rates by level of activity (distance traveled or energy) and emission process. The RunSpec, which we developed for running the emissions scenarios corresponding to the data inputs in the $2005 \mathrm{MNEI}$, also included urban and rural restricted and unrestricted access road types, as well as total mass of PM2.5 and PM10, for all vehicle types and gasoline and diesel fuel types. For this analysis, we have excluded the vehicle fleets powered by electricity, natural gas, and liquefied petroleum gas, as they represent only a very small fraction $(<1 \%)$ of the total vehicle fleets.

\section{Results and discussion}

\subsection{PM2.5 emission factors}

Total national PM2.5 emissions estimates from on-road mobile sources in the $2005 \mathrm{MNEI}$ are $11824 \mathrm{Mg} / \mathrm{yr}$, of which the Estado de México and the Distrito Federal are the larger contributors with 1393 and $1298 \mathrm{Mg} / \mathrm{yr}, 11.8$ and $10.9 \%$ respectively. The number of vehicles from the Estado de México and the Distrito Federal account together for $22.7 \%$ of the country's vehicle fleet. The analysis of the vehicle categories for the Mexican states indicates that gasoline-powered vehicles account for most of the total Mexican vehicle fleet, but there is considerable variability across states (see Fig. 1). For example, the Distrito Federal and the Estado de México together 
account for about $30 \%$ of the total national vehicle fleet, but have relatively smaller proportions of LDGT1 and LDGT2 compared to the rest of the states. Most of the northern states (like Baja California Norte, Nuevo León, Chihuahua, etc.) have large size vehicle fleets and have regularly distributed vehicle fleet compositions. Noticeably, the Distrito Federal, Hidalgo, and Campeche have vehicle fleet distributions with smaller numbers of LDGTs. Starting from 1999 new gasolinepowered vehicles in Mexico have to comply with stringent emissions standards that limit the emissions of gases and suspended particles. However, Table I shows that all Mexican states still have gasoline and diesel fleets with large fractions of older vehicles. Noticeable, several northern Mexican states tend to have fleets with larger fractions of older gasoline-powered vehicles than the rest of the country.

Table 1. Mexican gasoline and diesel vehicle. Fleet size and age.

\begin{tabular}{|c|c|c|c|c|c|c|}
\hline $\begin{array}{l}\text { State } \\
\text { ID }\end{array}$ & State & $\begin{array}{c}\text { Total vehicles } \\
\times 10^{6}\end{array}$ & $\begin{array}{c}\% \\
\text { LDGV }\end{array}$ & $\begin{array}{c}\% \\
\operatorname{diesel}^{1}\end{array}$ & $\begin{array}{l}\text { \% LDGV } \\
<1999 \mathrm{MY}\end{array}$ & $\begin{array}{c}\% \text { diesel } \\
<1998 \mathrm{MY}\end{array}$ \\
\hline 0 & Distrito Federal & 2.232 & 92.4 & 5.0 & 42.0 & 63.3 \\
\hline 1 & México & 1.969 & 75.2 & 6.7 & 60.6 & 68.8 \\
\hline 2 & Baja California & 1.638 & 74.7 & 0.6 & 83.8 & 74.1 \\
\hline 3 & Jalisco & 1.981 & 43.0 & 1.3 & 64.5 & 80.7 \\
\hline 4 & Nuevo León & 1.292 & 55.5 & 2.2 & 64.6 & 48.0 \\
\hline 5 & Hidalgo & 0.547 & 95.7 & 3.6 & 75.2 & 70.4 \\
\hline 6 & Chihuahua & 1.082 & 46.6 & 1.1 & 82.0 & 75.2 \\
\hline 7 & Guanajuato & 0.927 & 51.5 & 2.0 & 66.5 & 72.1 \\
\hline 8 & Michoacán & 1.034 & 44.8 & 1.0 & 78.0 & 82.9 \\
\hline 9 & Puebla & 0.844 & 48.7 & 3.2 & 57.9 & 72.4 \\
\hline 10 & Veracruz & 0.827 & 44.5 & 3.9 & 54.9 & 69.1 \\
\hline 11 & Tamaulipas & 0.831 & 41.9 & 1.9 & 71.6 & 61.6 \\
\hline 12 & Coahuila & 0.655 & 53.0 & 1.1 & 73.7 & 76.0 \\
\hline 13 & Sinaloa & 0.646 & 42.9 & 1.2 & 74.3 & 74.8 \\
\hline 14 & Guerrero & 0.424 & 63.3 & 3.9 & 67.5 & 53.0 \\
\hline 15 & San Luis Potosí & 0.308 & 65.9 & 4.1 & 75.0 & 64.9 \\
\hline 16 & Aguascalientes & 0.384 & 50.0 & 1.4 & 73.7 & 79.0 \\
\hline 17 & Yucatán & 0.332 & 51.9 & 1.5 & 70.8 & 67.0 \\
\hline 18 & Quintana Roo & 0.238 & 60.7 & 1.6 & 54.1 & 63.1 \\
\hline 19 & Durango & 0.365 & 39.6 & 1.3 & 73.4 & 85.4 \\
\hline 20 & Chiapas & 0.286 & 45.7 & 2.8 & 63.7 & 70.5 \\
\hline 21 & Zacatecas & 0.381 & 29.5 & 1.6 & 74.1 & 78.9 \\
\hline 22 & Querétaro & 0.270 & 41.5 & 3.4 & 55.7 & 53.4 \\
\hline 23 & Morelos & 0.188 & 58.8 & 1.4 & 59.3 & 69.7 \\
\hline 24 & Baja California Sur & 0.267 & 40.8 & 1.1 & 82.9 & 69.5 \\
\hline 25 & Oaxaca & 0.236 & 40.0 & 3.0 & 49.2 & 65.1 \\
\hline 26 & Tlaxcala & 0.204 & 43.6 & 2.0 & 67.9 & 81.2 \\
\hline 27 & Sonora & 0.184 & 46.0 & 3.2 & 88.9 & 78.8 \\
\hline 28 & Nayarit & 0.182 & 33.4 & 1.6 & 67.1 & 81.5 \\
\hline 29 & Campeche & 0.089 & 64.3 & 2.6 & 44.3 & 67.4 \\
\hline 30 & Colima & 0.138 & 35.7 & 2.0 & 60.2 & 58.1 \\
\hline 31 & Tabasco & 0.238 & 18.6 & 27.6 & 69.6 & 67.6 \\
\hline
\end{tabular}

${ }^{1}$ Diesel category includes light, medium and heavy-duty diesel vehicles. Source: SEMARNAT, 2011. 
Figure 1 shows that the state of Baja California (whose major urban areas are the US-Mexico border cities of Tijuana and Mexicali) have the largest number of cars per person ( 0.4 vehicles/ person), followed by the Distrito Federal ( 0.24 vehicles/person), whereas most of the rest of the states have 0.1 vehicles/person or less. In general, these are relatively low ratios of vehicles/ person; for example, the corresponding ratio of vehicles/person for Los Angeles for the year 2005 was 0.38 vehicles/person (CARB, 2010), which is similar to the neighbor state of Baja California.
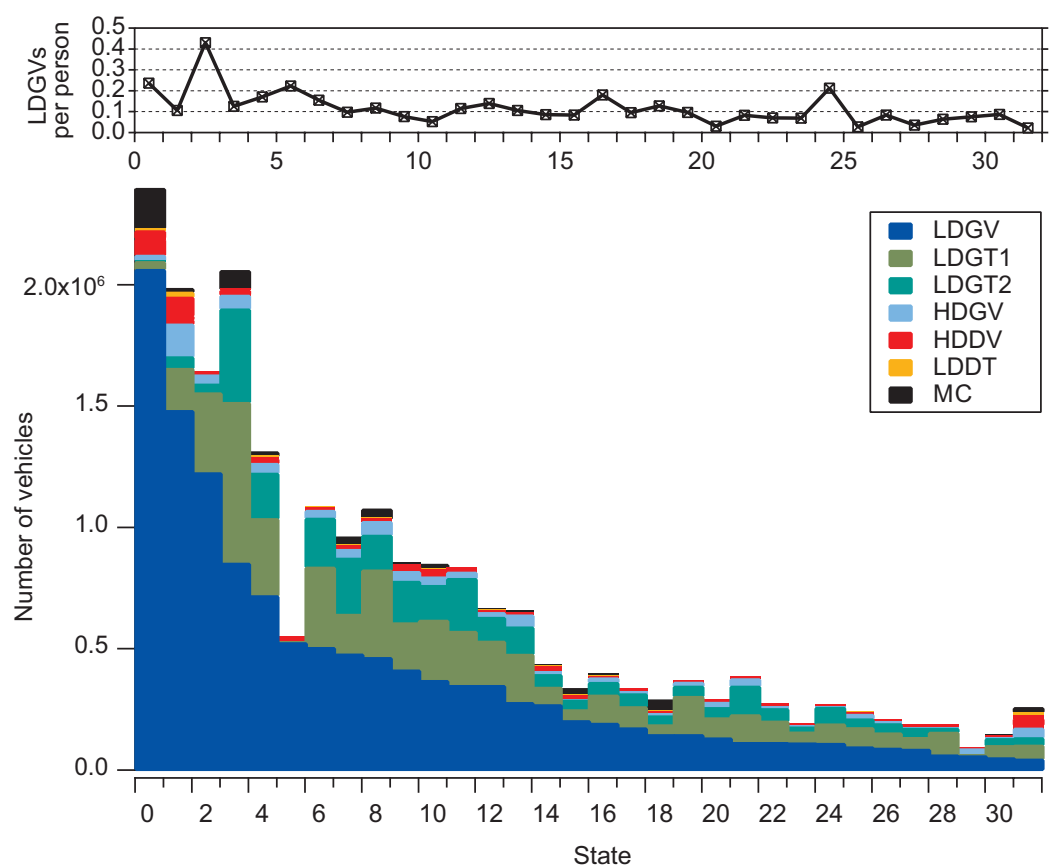

Fig. 1. Lower panel: Number of vehicles for Mexican states by vehicle type. Upper panel: Number of LDGV per habitant for Mexican states. The identification of the names of the states can be found in Table 1. LDGV: Light-duty gasoline vehicles; LDGT1: Light-duty gasoline trucks subtype 1; LDGT2: Light-duty gasoline trucks subtype 2; HDGV: Heavy-duty gasoline vehicles; HDDV: Heavy-duty diesel vehicles; LDDT: Light-duty diesel trucks; MC: Motorcycles.

Except for the state of Tabasco, all Mexican states show fractions of diesel-powered vehicle fleets smaller than $7.7 \%$. The data also indicates that the diesel-powered fleet is composed almost entirely of HDDV with only very small contributions of LDDT for all states. In turn, the fractions of gasoline-powered vehicles dominate compared to the rest of vehicle fleet type distributions. Most of the fractions of LDGV range between 40 and $60 \%$ of the overall vehicle fleet but there is large variability across states. Except for the Distrito Federal and Hidalgo, the fraction of LDGT fleets is similar in magnitude to the fraction of the LDGV fleet. The comparison suggests that the vehicle fleets in Mexico tend to have small fractions of diesel-powered vehicles and that gasoline-powered vehicles dominate the vehicle fleets with relatively high fractions of LDGVs followed by LDGTs. 
The variability of PM2.5 emission factors by vehicle model year is a critical difference between the MOVES2010 and the MNEI-2005 model results that has an important effect on the overall PM2.5 emission estimates. Figures 2, 3 show the comparison between PM2.5 emission factors obtained using the two models for various gasoline and diesel-powered vehicle types. The analyzed emission factors represent "bulk" conditions for each vehicle type category, i.e. the model's capability to account for parameters that affect PM2.5 emissions under the prescribed inputs. Thus the variability among estimated bulk PM2.5 emission factors across Mexican states corresponds to the differences in key input data for each state including average vehicle speed, sulfur content, and meteorology.

The results show large differences in magnitude for PM2.5 emission factors between gasoline and diesel-powered vehicles. However, the observed lack of variability by model year in the 2005 MNEI PM2.5 emission factors indicates that a zero deterioration rate was assumed for the estimation of PM2.5 emissions, and that changes in PM2.5 emission factors due to technological improvements were not considered in the 2005 MNEI. In contrast, the PM2.5 emission factors estimated using MOVES2010a with the equivalent input data in the 2005 MNEI also show large variability among bulk PM2.5 emission factors across Mexican states, but with decreasing trends for all vehicle categories by model years. Also, the results indicate that PM2.5 emission factors of older vehicles are significantly higher than for newer vehicles in the MOVES2010a. This effect is observed for both diesel and gasoline-powered vehicles, but it is more pronounced for the gasoline vehicle fleet. The differences in decreasing trends between gasoline-powered and dieselpowered vehicles are consistent with long-term analysis of data obtained from tunnel studies, in which observed changes in emissions have been attributed primarily to improvements in vehicle technology (Ban-Weiss et al., 2008; Bishop and Stedman, 2008).

With the exception of gasoline and diesel-powered passenger cars the comparison between MOVES2010a and MOBILE6.2 PM2.5 emission factors is not straightforward for various vehicle types because the vehicle type categories in MOVES2010a include vehicle population fractions of two or more MOBILE6.2 vehicle type categories (EPA, 2010). Still the comparison shown in Figures 2, 3 is informative. For example, MOBILE6.2-Mexico PM2.5 emission factors from HDGV are 3-4 times higher than for LDGV, but both are within the range of the gasoline-powered passenger and light commercial trucks in MOVES2010a (Fig. 2). Also, the PM2.5 emission factors from gasoline-powered passenger cars are much higher for older vehicles in the MOVES2010a compared to MOBILE6.2-Mexico estimates, but much smaller for the newer vehicles. For the diesel-powered vehicle fleet, the PM2.5 emission factors from LDDV and LDDT are higher than the corresponding estimates of diesel-powered passenger and light commercial trucks in MOVES2010a. However, the population fraction of LDDV and LDDT vehicle types is smaller than the population fraction of HDDV and very small compared to the overall Mexican vehicle fleet population distributions. The PM2.5 emission factors from HDDV8V (class 8 heavy-duty diesel vehicles) are within the range of the diesel-powered combination and single unit shorthaul trucks in MOVES2010a.

\subsection{PM2.5 emissions}

The results presented in Figures 2, 3 suggest that higher fractions of older vehicles would tend to increase PM2.5 emissions estimates using MOVES2010a with respect to the $2005 \mathrm{MNEI}$ estimates. For example, since the age distributions of HDDV8V have high fractions of older vehicles the PM2.5 emissions from older vehicles would be underestimated for this vehicle type, 

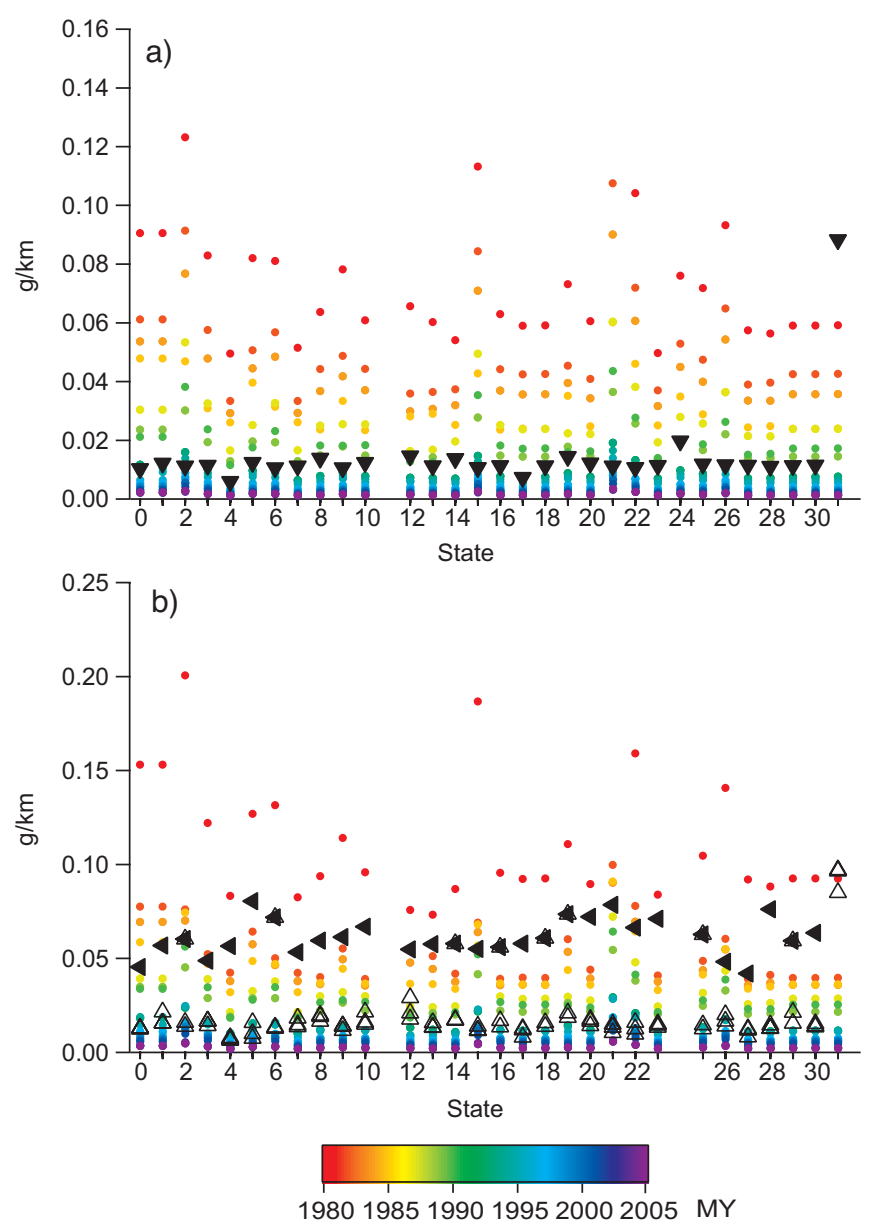

Fig. 2. Comparison of PM2.5 emissions factors obtained with MOVES2010a (dots colored by vehicle model year, MY) and MOBILE6.2-Mexico for each Mexican state for gasoline-powered vehicles types: (a) Passenger cars in MOVES2010a (colored dots) and LDGV in MOBILE6.2Mexico (black triangles), (b) Passenger trucks in MOVES2010a (colored dots), and HDGV3 and LDGT3 (black and open triangles, respectively) in MOBILE6.2Mexico. The identification of the names of the Mexican states can be found in Table 1 .

whereas the PM2.5 emissions from newer diesel trucks would be overestimated with respect to MOVES2010a. However, the overall impact of these differences will vary depending on the vehicle population and age composition for each Mexican state fleet. As an example, Figure 4 shows a comparison of PM2.5 emissions for LDGV and HDDV8V vehicle categories for the Distrito Federal using the calculated MOVES2010a PM2.5 emission factors and the corresponding 2005 MNEI estimates. In both cases the MNEI PM2.5 emission estimates for older vehicles are largely underestimated with respect to MOVES2010a whereas the PM2.5 emissions estimates for newer vehicles are overestimated. Overall both effects are compensated and the total emissions estimates for the Distrito Federal are rather similar. However, data from the MNEI indicates that the vehicle age composition varies widely among Mexican states (e.g., the percentages of 1999 vehicles or older are 57.5 and $16.5 \%$ for the Distrito Federal and Michoacán, respectively), indicating that the overall impact of these differences will vary depending on the vehicle age composition for each Mexican state fleet.

These results are consistent with recent studies aimed at comparing model estimates of PM2.5 emissions between MOBILE6.2 and MOVES2010 by EPA. These comparative studies have shown that MOVES2010 provides higher estimates of PM2.5 emissions for both light and heavy-duty vehicles and for all of the US urban areas modeled (EPA, 2010; Claggett, 2010). In those studies, 

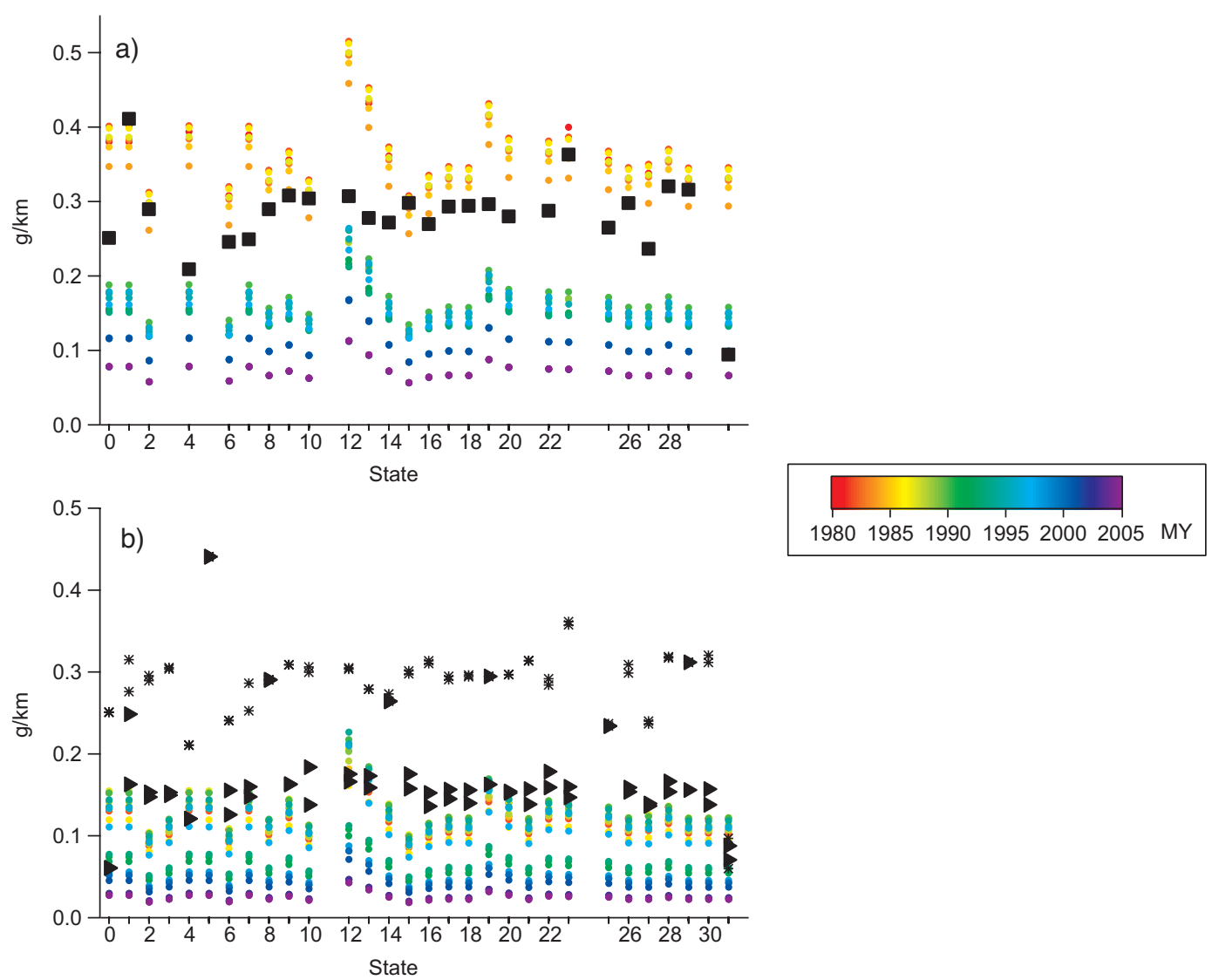

Fig. 3. Comparison of PM2.5 emissions factors obtained with MOVES2010a (dots colored by vehicle model year, MY) and MOBILE6.2-Mexico for diesel-powered vehicles types: (a) Combination shorthaul trucks in MOVES2010a (colored dots) and HDDV8V in MOBILE6.2-Mexico (black squares); (b) Light commercial trucks in MOVES2010a (colored dots), LDDT (triangles), and HDDV3 and HDDV5 (asterisks) in MOBILE6.2-Mexico. The identification of the names of the Mexican states can be found in Table 1.

the differences in PM emissions estimates arise in part due to the substantial influence of vehicle speed (including idling), crankcase emissions, and temperature that are accounted differently in the two models. The results of the comparative analysis indicate that using MOVES2010a to estimate PM2.5 emissions from mobile sources in Mexico will increase the current emission estimates for older vehicles and decrease the estimates for newer vehicles obtained by using the MOBILE6.2Mexico model. The inclusion of other emission processes (e.g., brake wear, tire wear, crankcase, well-to-pump, etc.) would further increase the differences in the overall PM2.5 emissions estimates.

It is important to identify the key parameters that affect PM2.5 emission estimates using the recent developments in MOVES2010a. An analysis of the data inputs used for estimating the PM2.5 emissions from mobile sources in the 2005 MNEI indicates that the average vehicle speed and temperature had the highest sensitivity on the MOVES2010a PM2.5 emission factors estimates. In general, PM2.5 emission factors were higher for higher average vehicle speeds, consistent with studies indicating higher PM emission rates observed under high engine load conditions (i.e., vehicle 


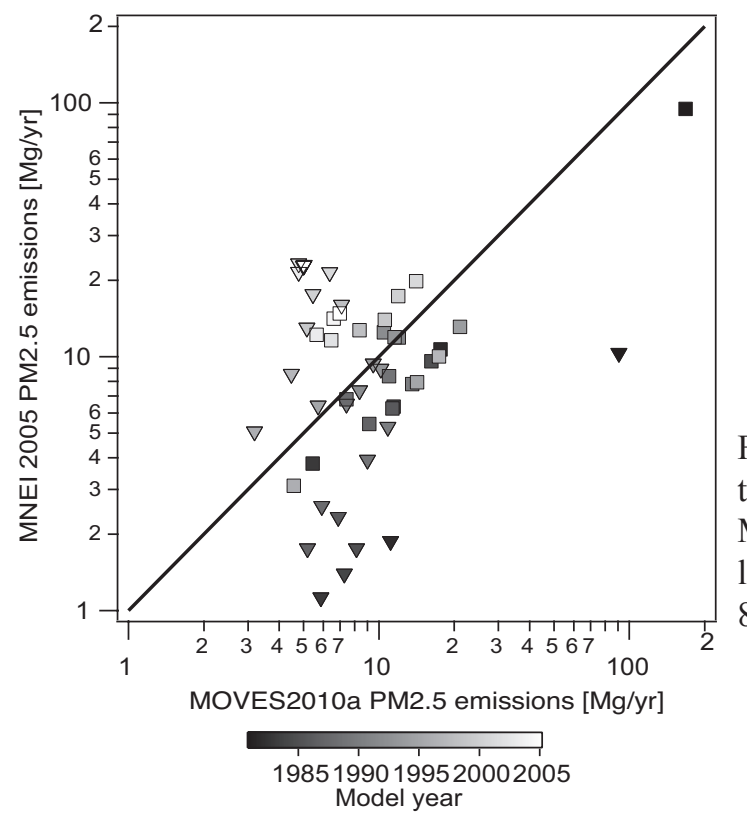

Fig. 4. Comparison of PM2.5 emission estimates for the Distrito Federal between the MOVES2010a and MOBILE6.2-Mexico using the MNEI 2005 inputs for light-duty gasoline vehicles (LDGV, triangles) and class 8 heavy-duty diesel vehicles (HDDV8V, squares).

speeds) (Kean et al., 2003; Cadle et al., 2007; Zavala et al., 2009b). Similarly, recent studies are consistent with the observation that fine PM emissions increase with engine load for diesel-powered engines and that volatile fraction of fine PM decreases with increasing load (Ziemmann et al., 2002; Kwon et al., 2003). This can be explained by the high fraction of unburned lubricating oil observed in the PM exhausts with respect to combustion oxidation products and unburned fuel.

The 2005 MNEI used only a limited range of sulfur content in gasoline and diesel fuels. An average sulfur content of 300 or 500 ppm was assumed for all Mexican states, except for the Distrito Federal and the Estado de México with an average sulfur content of $244 \mathrm{ppm}$. Two additional sensitivity cases for the Distrito Federal were run to evaluate the possible effects of sulfur content in fuel in the MOVES2010a estimates. In the first scenario the average sulfur content in gasoline for the Distrito Federal was decreased from $244 \mathrm{ppm}$ to $50 \mathrm{ppm}$; in the second scenario the average sulfur content in diesel was decreased from $500 \mathrm{ppm}$ to $50 \mathrm{ppm}$ (ultra-low sulfur diesel); the results are shown in Figure 5.

The results from the first sulfur sensitivity scenario showed decreases of estimated PM2.5 emissions from gasoline-powered private cars in the range of $0.3-6.2 \%$ (average 2.2\%), varying by vehicle model year. In the second sulfur sensitivity scenario, the PM2.5 emission factors for the diesel-powered vehicles were reduced in the range of 1.3-6.7\% (average 3.4\%). In both scenarios, the higher/lower decreases occurred in the newer/older vehicle types, but this may change for fleets with different vehicle age composition. Due to its role in varying the rates of nucleationcondensation processes, sulfur content in fuel and lubricating oil can also have an important role in the mass and number of fine PM emitted from mobile sources. Overall, studies have consistently reported that the presence of sulfur in fuel and lubricating oil increase the mass of emitted fine PM, but their size distributions vary depending on the availability of organic and soot fractions in the exhaust (Vaaraslahti et al., 2005; Ristovski et al., 2006). Although sulfate typically constitutes a small fraction of total emitted fine PM (particularly for diesel-powered vehicles without a diesel 


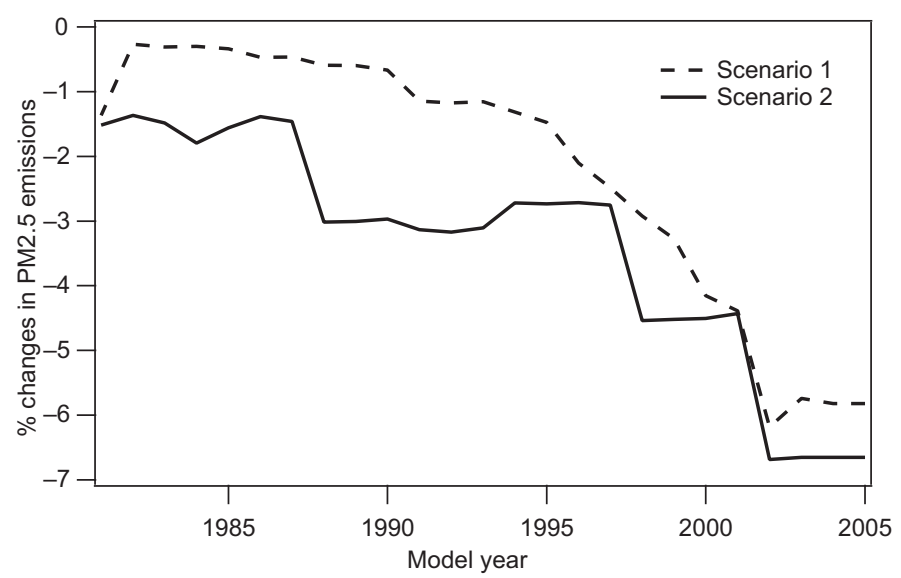

Fig. 5. Percentage changes in PM2.5 emission estimates with respect to 2005 PM2.5 emissions in the Distrito Federal resulting from sulfur content reduction in fuels. Scenario 1: S reduction from 244 to $50 \mathrm{ppm}$ in gasoline for gasoline-powered vehicles; Scenario 2: S reduction from 500 to $50 \mathrm{ppm}$ in diesel for dieselpowered vehicles.

particle filter), the presence of sulfur in the fuel increases the total mass of fine PM emitted due to increases in the rate of nucleation-condensation processes. Nucleation of $\mathrm{H}_{2} \mathrm{SO}_{4}$ particles in the exhaust may be favored by extreme dilution after leaving the vehicle, and organic compounds may condense on the sulfate particles.

We have performed sensitivity scenarios for estimating the effects on PM2.5 emissions due to changes in average ambient temperature in the range of $6-17{ }^{\circ} \mathrm{C}$. The results indicated linear decreases of PM2.5 emissions from gasoline powered vehicles by increasing temperature, but no changes on estimated PM2.5 emissions from diesel powered vehicles. The linear increases on PM2.5 were in the range of 4.2-5.5\% change on emissions by 1 degree. However, these temperature effects on PM2.5 emissions had very limited variations by vehicle model year. The model showed no sensitivity effects on PM2.5 emissions from diesel powered vehicles to changes in average relative humidity.

These results highlight the importance of continuous improvement in gathering local data on key input parameters during the estimation of PM2.5 emissions for mobile sources. The PM2.5 emission factors estimates will strongly benefit from the use of locally-representative validated input parameters that can be obtained from combined measurements-based and model-based studies. It is also important to implement "top-down" evaluations of PM2.5 emissions estimates in emissions inventories developed for major urban areas in Mexico other than Mexico City. Controlled, dedicated studies for the measurement-based evaluations of PM2.5 emission factors estimated in current mobile emissions models can reduce the uncertainties during the estimation of PM2.5 emissions from mobile sources in Mexico. Due to their higher emission rates and their large population fractions in the Mexican vehicle fleets, this evaluation should be preferentially directed towards the measurement of PM2.5 emission factors of older vehicles for both gasoline and diesel-powered vehicles. 


\section{Conclusions}

In this study we present results of the evaluation of possible impacts of recent studies and modelbased databases of PM2.5 emissions factors for their potential use in estimating PM2.5 emissions from mobile sources in Mexico. A literature review of studies on emissions from mobile sources in Mexico indicates that there is a large gap of measurements and information on emissions from vehicle fleets in most urban areas of the country, and that most of the information gathered has focused on the gas-phase emissions from gasoline-powered vehicles. Therefore, there is a strong need for a better understanding of the characteristics of fine PM emitted from diesel-powered vehicles in major urban areas in Mexico.

Comparison of the vehicle fleet characteristics shows that gasoline-powered vehicles dominate over the diesel-powered vehicle fleets with relatively high fractions of LDGVs followed by LDGTs in Mexican fleets. Mexican vehicle fleets have relatively higher fractions of older vehicles and large variability across Mexican states. The data also suggests that gasoline-powered vehicle fleets in Mexico have relatively high fractions of vehicles without emission control technology.

The results suggest that higher fractions of older vehicles would tend to increase PM2.5 emissions estimates using MOVES2010a with respect to the 2005 MNEI estimates. However, the overall impact of these differences will vary depending on the vehicle population and vehicle age composition for each Mexican state fleet, with PM2.5 emissions being underestimated for older vehicles whereas PM2.5 emissions estimates for newer vehicles would be overestimated. The effects are primarily driven by the higher PM2.5 emission factors from the gasoline-powered vehicles and by high fractions of older gasoline and diesel vehicles. The inclusion of other emission processes (e.g., brake wear, tire wear, crankcase, well-to-pump, etc.) would further increase the differences in the overall PM2.5 emissions estimates. The estimated MOVES2010a PM2.5 emission factors for Mexico were particularly sensitive to vehicle speed, ambient temperature and sulfur content.

\section{Acknowledgments}

We would like to thank the Commission for Environmental Cooperation for their support in developing this research, especially to Orlando Cabrera-Rivera, Program Manager for Air Quality and Pollutant Releases, for his assistance in obtaining the information used in this study. We are grateful to Ramiro Barrios from SEMARNAT and Angélica Velázquez for providing the data used in our analysis.

\section{References}

Aiken A. C., D. Salcedo, M. J. Cubison, J. A. Huffman, P. F. DeCarlo, I. M. Ulbrich, K. S. Docherty, D. Sueper, J. R. Kimmel, D. R. Worsnop, A. Trimborn, M. Northway, E. A. Stone, J. J. Schauer, R. M. Volkamer, E. Fortner, B. de Foy, J. Wang, A. Laskin, V. Shutthanandan, J. Zheng, R. Zhang, J. Gaffney, N. A. Marley, G. Paredes-Miranda, W. P. Arnott, L. T. Molina, G. Sosa and J. L. Jiménez, 2009. Mexico City aerosol analysis during MILAGRO using high-resolution aerosol mass spectrometry at the urban supersite (T0). Part 1: Fine particle composition and organic source apportionment, Atmos. Chem. Phys. 9, 6633-6653, doi:10.5194/acp-9-6633-2009.

Bachmann J. D., 2010. The health effects of particles 2010: New science, old issues. Air \& Waste Manegement Association. EM, September, 5 [http://www.awma.org/App_Themes/Public/Docs/ em/pdfs/2010/9/bachmannintro.pdf]. 
Ban-Weiss G., J. McLaughlin, R. Harley, M. Lunden, T. Kirchstetter, A. Kean, A. Strawa, E. Stevenson and G. Kendall, 2008. Long-term changes in emissions of nitrogen oxides and particulate matter from on-road gasoline and diesel vehicles. J. Atmos. Environ. 42, 220-232.

Beaton S. P., G. A. Bishop and D. H. Stedman, 1992. Emission characteristics of Mexico City vehicles. J. Air Waste Manage. 42, 1424-1429.

Bishop G., D. Stedman, J. de la Garza Castro and F. Dávalos, 1997. On-road remote sensing of vehicle emissions in Mexico. J. Environ. Sci. Technol. 31, 3505-3510.

Bishop G. and D. Stedman, 2008. A decade of on-road emissions measurements. J. Environ. Sci. Technol. 42, 1651-1656.

Cadle S. H., A. Ayala, K. N. Black, C. R. Fulper, R. R. Graze, F. Minassian, M. Natarajan, C. J. Tennant and D. R. Lawson, 2007. Real-world vehicle emissions: a summary of the Sixteenth Coordinating Research Council On-Road Vehicle Emissions Workshop. J. Air Waste Manage. 57, 139-145.

CARB, 2010. EMFAC2007 version 2.30. Calculating emission inventories for vehicles in California. User's Guide (draft version). California Air Resources Board. http://www.arb.ca.gov/msei/ onroad/latest_version.htm [last accessed: Jan 2011].

Claggett M., 2010. Implications of the MOVES2010 model on mobile source emissions estimates Air \& Waste Manegement Association. EM, July, 10-15 [http://pubs.awma.org/gsearch/ em/2010/7/claggett.pdf].

CRC, 2007. Characterization of ultrafine and fine particulate matter emissions from heavy-duty diesel vehicles. Coordinating Research Council Report No. E-55-59 1.5a.

CRC, 2010. Diesel unregulated emissions characterization. Coordinating Research Council Report No. E-75-2.

Díaz L., I. Schifter, E. López-Salinas, E. Gamas, R. Rodríguez and S. Ávalos, 2000. Optimizing automotive LPG blend for Mexico City. Fuel 79, 79-88.

EPA, 2008. Kansas City PM characterization study. Final report. US-Environmental Protection Agency 420-R-08-009.

EPA, 2010. Technical guidance on the use of MOVES2010 for emission inventory preparation in state implementation plans, transportation conformity. US-Environmental Protection Agency420-B-10-023.

Gamas E. D., L. Díaz, R. Rodríguez, E. López-Salinas and E. Schifter, 1999. Exhaust emissions from gasoline- and LPG-powered vehicles operating at the altitude of Mexico City. J. Air Waste Manage. 49, 1179-1189.

Jazcilevich A., A. García-Fragoso, A. García, M. Grutter, U. Diego-Ayala, J. Lents and N. Davis, 2007. A vehicle emissions system using a car simulator and a GIS. J. Air Waste Manage. 57, 1234-1240.

Jiang M., L. C. Marr, E. J. Dunlea, S. C. Herndon, J. T. Jayne, C. E. Kolb, W. B. Knighton, T. M. Rogers, M. Zavala, L. T. Molina and M. J. Molina, 2005. Mobile laboratory measurements of black carbon, polycyclic aromatic hydrocarbons and other vehicle emissions in Mexico City. Atmos. Chem. Phys. 5, 3377-3387.

Kean A. J., R. A. Harley and G. R. Kendall, 2003. Effects of vehicle speed and engine load on motor vehicle emissions. J. Environ. Sci. Technol. 37, 3739-3746.

Kwon S. B., K.W. Lee, K. Saito, O. Shinozaki and T. Seto, 2003. Size-dependent volatility of diesel nanoparticles: Chassis dynamometer experiments. J. Environ. Sci. Technol. 37, 1794-1802. 
Molina L. T., C. E. Kolb, B. de Foy, B. K. Lamb, W. H. Brune, J. L. Jiménez, R. Ramos-Villegas, J. Sarmiento, V. H. Páramo-Figueroa, B. Cárdenas, V. Gutiérrez-Avedoy and M. J. Molina, 2007. Air quality in North America's most populous city_overview of the MCMA-2003 campaign. Atmos. Chem. Phys. 7, 2447-2473.

Molina L. T., S. Madronich, J. S. Gaffney, E. Apel, B. de Foy, J. Fast, R. Ferrare, S. Herndon, J. L. Jimenez, B. Lamb, A. R. Osornio-Vargas, P. Russell, J. J. Schauer, P. S. Stevens, R. Volkamer and M. Zavala, 2010. An overview of the MILAGRO 2006 campaign: Mexico City emissions and their transport and transformation. Atmos. Chem. Phys. 10, 8697-8760.

Múgica V., E. Vega, J. Arriaga and M. Ruiz, 1998. Determination of motor vehicle profiles for non-methane organic compounds in the Mexico City metropolitan area. J. Air Waste Manage. 48,1060-1068.

Osornio A., J. Serrano, L. Rojas-Bracho, J. Miranda, C. García-Cuéllar, M. Reyna, G. Flores, M. Zuk, M. Quintero, I. Vázquez, Y. Sánchez-Pérez, T. López and I. Rosas, 2011. In vitro biological effects of airborne PM2.5 and PM10 from a semi-desert city on the Mexico-US border. Chemosphere 83, 618-626.

Pope C. A., 2010. Human health effects of particulate matter air pollution. J. Air Waste Manage. EM, 6-11.

Quintana R., J. Serrano, V. Gómez, J. Miranda, C. García-Cuéllar, B. de Foy, E. Vega, L.T. Molina, N. Manzano-León, I. Rosas and A. R. Osornio-Vargas, 2011. Oxidative potential and cellular effects induced by PM10 obtained in Mexico City and at a receptor site during the MILAGRO campaign. Environ. Pollut. 159, 3446-3454.

Ristovski Z. D., E .R. Jayaratne, L. Lin, G. A. Ayoko and L. Morawska, 2006. Influence of diesel fuel sulfur on nanoparticle emissions from city buses. J. Environ. Sci. Technol. 40, 1314-1320.

Riveros H. G., A. Alba, P. Ovalle, B. Silva and E. Sandoval, 1998. Carbon monoxide trend, meteorology, and three-way catalysts in Mexico City. J. Air Waste Manage. 48, 459-462.

Riveros H. G., E. Cabrera and P. Ovalle, 2002. Vehicle inspection and maintenance, and air pollution in Mexico City. Transport. Res. D-Tr. E. 7, 73-80.

Rogers, T. M., E. P. Grimsrud, S. C. Herndon, J. T. Jayne, C. E. Kolb, E. Allwine, H. Westberg, B. K. Lamb, M. Zavala, L. T. Molina, M. J. Molina and W. B. Knighton, 2006. On-road measurements of volatile organic compounds in the Mexico City metropolitan area using proton transfer reaction mass spectrometry. J. Mass Spectrom. 252, 26-37.

Schifter I., L. Díaz, E. López-Salinas, R. Rodríguez, S. Ávalos and V. Guerrero, 2000a. An evaluation of the LPG vehicles program in the metropolitan area of Mexico City. J. Air Waste Manage. 50, 301-309.

Schifter I., L. Díaz, E. López-Salinas and S. Ávalos, 2000b. Potential impacts of compressed natural gas in the vehicular fleet of Mexico City. J. Environ. Sci. Technol. 34, 2100-2104.

Schifter I., L. Díaz, S. Ávalos, M. Vera, A. Barrera and E. López-Salinas, 2000c. Effect of methyl tertiary butyl ether concentrations on exhaust emissions from gasoline used in the metropolitan area of Mexico City. J. Air Waste Manage. 50, 488-494.

Schifter I., L. Díaz, M. Vera, M. Castillo, F. Ramos, S. Ávalos and E. López-Salinas, 2000d. Impact of engine technology and vehicular emissions in Mexico City. J. Environ. Sci. Technol. 34, 2663-2667.

Schifter I., L. Díaz, E. López-Salinas, F. Ramos, S. Ávalos, G. López-Vidal and M. Castillo, 2000e. Estimation of motor vehicle toxic emissions in the metropolitan area of Mexico City. J. Environ. Sci. Technol. 34, 3606-3610. 
Schifter I., M. Vera, L. Díaz, E. Guzmán, F. Ramos and E. López-Salinas, 2001. Environmental implications on the oxygenation of gasoline with ethanol in the metropolitan area of Mexico City. J. Environ. Sci. Technol. 35, 1893-1901.

Schifter I., L. Díaz, M. Vera, E. Guzmán and E. López-Salinas, 2003a. Impact of sulfur in gasoline on motor vehicle emissions in the metropolitan area of Mexico City. Fuel 82, 1605-1612.

Schifter I., L. Díaz, M. Vera, E. Guzmán, F. Ramos and E. López-Salinas, 2003b. Evaluation of the inspection/maintenance program in the metropolitan area of Mexico City. J. Environ. Sci. Technol. 37, 196-200.

Schifter I., L. Díaz, J. Durán, E. Guzmán, O. Chávez and E. López-Salinas, 2003c. Remote sensing of emissions from motor vehicles in the metropolitan area of Mexico City. J. Environ. Sci. Technol. 37, 395-401.

Schifter I., L. Díaz, M. Vera, E. Guzmán and E. López-Salinas, 2004. Fuel formulation and vehicle exhaust emissions in Mexico. Fuel 83, 2065-2074.

Schifter I., L. Díaz, R. Rodríguez, J. Durán and O. Chávez, 2008. Trends in exhaust emissions from in-use Mexico City vehicles, 2001-2006. A remote sensing study. Environ. Monit. Assess. 137, 459-470.

SEMARNAT, 2006. Inventario Nacional de Emisiones de México, 1999. México: Secretaría de Medio Ambiente y Recursos Naturales-Instituto Nacional de Ecología.

SEMARNAT, 2011. Inventario Nacional de Emisiones de México 2005. México: Secretaría de Medio Ambiente y Recursos Naturales-Instituto Nacional de Ecología.

Thornhill D. A., A. E. Williams, T. B. Onasch, E. Wood, S. C. Herndon, C. E. Kolb, W. B. Knighton, M. Zavala, L. T. Molina and L. C. Marr, 2010. Application of positive matrix factorization to on-road measurements for source apportionment of diesel and gasoline-powered vehicle emissions in Mexico City. Atmos. Chem. Phys. 10, 3629-3644, doi:10.5194/acp-10-3629-2010.

Vaaraslahti K., J. Keskinen, B. Giechaskiel, A. Solla, T. Murtonen and H. Vesala, 2005. Effect of lubricant on the formation of heavy-duty diesel exhaust nanoparticles. J. Environ. Sci. Technol. 39, 8497-8504.

Zavala M., S. C. Herndon, R. S. Slott, E. J. Dunlea, L. C. Marr, J. H. Shorter, M. Zahniser, W. B. Knighton, T. M. Rogers, C. E. Kolb, L. T. Molina and M. J. Molina, 2006. Characterization of on-road vehicle emissions in the Mexico City metropolitan area using a mobile laboratory in chase and fleet average measurement modes during the MCMA-2003 field campaign, Atmos. Chem. Phys. 6, 5129-5142.

Zavala M., S. C. Herndon, E. C. Wood, T. Onash, B. Knighton, L. Marr, C. Kolb and. L. T. Molina, 2009a. Evaluation of mobile emissions contributions to Mexico City's emissions inventory using on-road and cross-road emission measurements and ambient data. Atmos. Chem. Phys. 9, 6305-6317.

Zavala M., S. C. Herndon, E. C. Wood, J. T. Jayne, D. D. Nelson, A. M. Trimborn, E. Dunlea, W. B. Knighton, A. Mendoza, D. T. Allen, C. E. Kolb, M. J. Molina and L. T. Molina, 2009b. Comparison of emissions from on-road sources using a mobile laboratory under various driving and operational sampling modes. Atmos. Chem. Phys. 9, 1-14.

Zavala M., W. Lei, M. J. Molina and L. T. Molina, 2009c. Modeled and observed ozone sensitivity to mobile-source emissions in Mexico City. Atmos. Chem. Phys. 9, 39-55.

Ziemann P. J., H. Sakurai and P. H. McMurry, 2002. Chemical analysis of diesel nanoparticles using a nano-DMA/thermal desorption particle beam mass spectrometer. Final report of the CRC Project No. E-43-4. Alpharetta, GA: Coordinating Research Council. 